\title{
Right-wing Terrorism in the 21st Century: The National Socialist Underground and the history of terror from the far right in Germany by Daniel Koehler (Routledge, 2017) and Understanding Deradicalization: Methods, tools and programs for countering violent extremism by Daniel Koehler (Routledge, 2017)
}

\section{by Cynthia Miller-Idriss}

\section{(cc) $\mathrm{EY}$}

This work is licensed under a Creative Commons Attribution 3.0 License.

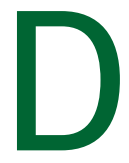
aniel Koehler's formidable pair of books about terrorism and extremist violence offer a remarkable synthesis of scholarly and practical knowledge about pathways into and out of violent extremism. In Right-Wing Terrorism in the $21^{\text {st }}$ Century, Koehler brings to an English-language audience one of the most pernicious terrorism cases of the past quarter-century through an analysis of German government documents, court verdicts, press reports and terrorism databases. The National Socialist Underground (NSU)'s terrorist activities took place over a decade, ultimately perpetrating ten assassinations, three bombings and fourteen bank robberies between 1998 and 2011. Koehler uses the NSU and the case of rightwing terrorism in Germany as a focal point, but situates the NSU and German cases within a broader analysis of right-wing terrorism post-World War II across Europe and North America.

Following a thorough review of the academic scholarship on right-wing terrorism at the first section of the book, Koehler turns in Chapter 3 to the challenge of defining the term "right-wing terrorism." He argues that right-wing terroristic activity needs to be considered separately from broader categories like "hate crimes" or "right-wing violence," which may lack the political and ideological underpinnings that motivate right-wing terrorism. The highlight of this section is Koehler's original analysis of the role that an ideology of violence plays in the communication strategies, tactics, and activities of right-wing terrorists. Violence, Koehler argues, is "not only a means to reach a certain political goal but [is] also the core essence" of rightwing terrorism (p. 55). The ritualization of violence, the clear demarcation of boundaries between 'us' and 'them,' between enemies and comrades, and the militaristic aim to eradicate weaker and inferior ethnic and racial groups in order to purify the nation are at the core of right-wing ideology, Koehler contends, and this ideology "cannot be understood or separated from violence in any form" (p. 56). In the second half of this chapter, Koehler creates a typology of right-wing criminal activity, ranging from non-political crimes, hate crimes, right-wing violence and right-wing terrorism. This latter category, the focus of this book, is defined by Koehler as an "escalated form of right-wing violent hate crimes" (p. 63). In the conclusion to this chapter, Koehler explicitly teases out similarities between right-wing terrorism and other forms of terrorism.

In Chapters 4 and 5, Koehler builds on the definitional and theoretical work done in the first parts of the book as he offers a detailed analysis of right-wing terrorism in Germany, focusing in particular on the case of the NSU but embedding that analysis within the broader context of far right wing violence in Germany post-World War II. These two sections are perhaps the most important parts of the book from a scholarly perspective, as they fill a surprising existing gap in the English-language literature on German right-wing 


\section{Journal of Terrorism Research}

terrorism and thus make an important contribution to the global and comparative discourse on terrorism and extremism. Chapter 6 turns to an analysis of the intelligence and police agencies, delving into the frequently-asked question of how the NSU could have escaped detection for so long. Koehler narrates the historical account of failures across the military intelligence, domestic intelligence and federal and state criminal police agencies, ultimately arguing while the NSU's success in escaping detection was partly due to poor organization and lack of communication and coordination across these agencies, it can also be attributed to a major failure in the cultural assumptions underpinning authorities' work. Authorities drastically underestimated the capabilities of the far right for terroristic violence, leading them to consistently misattribute the murders of immigrants, for example, as being tied to in-fighting within the immigrant community. Because far right research has primarily focused on formal political parties, prison inmates, or youth subcultures like skinheads, Koehler argues, German policy and intervention paradigms tended to see far right violence through these lenses and not as something that could be strategically organized and planned. If I have one complaint about this book, it is that this latter point-one of the most astute critiques of the scholarship and policymaking on far right wing extremism and violence in recent memory-is not highlighted in greater depth. Pointing out that existing work has led to blind spots in not only scholarship but also in the very paradigms that intelligence officers and police officers hold about the violent, terroristic or extremist potential of any given group is a key contribution, and should be highlighted much more.

The empirical portions of the book wrap up in Chapters 7 and 8 with a description of right-wing terrorist metrics and German right-wing terrorist actors over the past fifty years. In his conclusion, Koehler aptly summarizes his overall arguments and traces lessons learned as well as directions for future research. RightWing Terrorism in the $21^{\text {st }}$ Century is essential reading for scholars of terrorism and violence and will be a key source for policymakers, government analysts and intervention experts as well.

It is this latter category-interventionists and educators-to whom Koehler turns in his companion book, Understanding Deradicalization, in which he offers the first comprehensive synthesis of academic and practitioner knowledge about pathways away from extremism. Following an overview of the range of violent engagements to which de-radicalization can apply_-from Jihadist fighters to urban gangs and cults-Koehler traces theoretical understandings of the radicalization and deradicalization processes and offers a typology of deradicalization and disengagement programs. While written for an English-language audience, one of the most important contributions is Koehler's integration of additional source material and scholarship written in his native German language, thereby making a field of (national) knowledge available to a global audience.

In Chapter 6, Koehler introduces family counseling as a special case of deradicalization, highlighting innovative programs from France, Germany, the Netherlands, Denmark and elsewhere to show how community-based, public-private partnerships between local police agencies, social workers, educators and families are working to prevent violent radicalization and rehabilitate returnees and violent offenders. Koehler points out the critical role of trust in the success of these partnerships and shows how family counseling programs work within a broader network of authorities, schools, religious organizations and youth agencies, ultimately concluding that these models are "a very promising and innovative approach to tackle the issue of home-grown radicalization processes leading to violence and terrorism” (p. 158).

Chapter 7 tackles what is perhaps the most central question asked of any intervention program: does it work? Koehler analyzes standards, program design, and evaluation across programs in an effort to tease out best practices for measuring impact. While careful to disavow any 'one size fits all' approach, Koehler argues that it is possible-and imperative-to establish clear methods for evaluating the effectiveness of deradicalization 


\section{Journal of Terrorism Research}

and rehabilitation programs. This chapter makes a broad leap forward in analyzing the range of approaches that exist and is a critical starting point for opening the conversation around standards and methods for evaluation. Practitioners and policymakers would do well to spend the time required for an in-depth read. This is also the case for Chapter 9, when Koehler turns to tools and methods for deradicalization work, focusing on identifying standard tools used in the field. While still integrated into the kind of academic analysis that makes this book a true integration of scholarly and applied work, this chapter is the clearest and most accessible for practitioners, offering critical descriptions of intervention strategies like the role of former extremists, mentoring, the creative arts, vocational training, sports, and psychological counseling.

At a moment when the U.S. government is contemplating a major change in countering-violent-extremism (CVE) strategy in order to focus only on Islamist extremism, Koehler's analysis of deradicalization-which integrates examples of practitioner work across the spectrum of extremist violence-is a critical intervention in the literature. Together with its companion book on right-wing extremism, this pair of books makes a deeply significant contribution to the global scholarship on extremism engagement, radicalization and deradicalization. For scholars, practitioners, and policymakers working on terrorism, youth violence, radicalization or deradicalization, these are must reads.

\section{About the reviewer}

Dr. Cynthia Miller-Idriss is associate professor of education and sociology at American University in Washington, D.C., where she also directs the International Training and Education Program and runs the biannual Global Education Forum. Her most recent book, The Extreme Gone Mainstream: Commercialization and Far Right Youth Culture in Germany, is in press at Princeton University Press. 